\title{
Two New Genus Records for Turkish Helotiales
}

\author{
${ }^{*}$ Ilgaz AKATA ${ }^{1}$ Abdullah KAYA ${ }^{2}$, Yasin UZUN ${ }^{2}$ \\ ${ }^{1}$ Ankara University, Faculty of Science, Department of Biology, 06100, Tandoğan, Ankara Turkey \\ ${ }^{2}$ Karamanoğlu Mehmetbey University, Kâmil Özdağ Science Faculty, Department of Biology, Karaman- \\ Turkey \\ *Corresponding Author: fungus@ hotmail.com.tr \\ Geliş Tarihi: 07.11.2015
}

\begin{abstract}
Two members of order Helotiales, Catinella olivacea (Batsch) Boud. (Dermateaceae) and Belonidium sulphureum (Fuckel) Raitv. (Hyaloscyphaceae) are recorded from Turkey for the first time at generic level. Short descriptions and photographs of the species are provided.

Keywords: Catinella olivacea, Belonidium sulphureum, new records, Turkey

Özet

\section{Türkiye Helotiales'leri İçin İki Yeni Cins Kaydı}

Helotiales ordosunun iki üyesi Catinella olivacea (Batsch) Boud. (Dermateaceae) ve Belonidium sulphureum (Fuckel) Raitv. (Hyaloscyphaceae) Türkiye'den ilk defa cins düzeyinde kayıt edilmiştir. Türlerin kısa deskripsiyonları ve fotoğrafları verilmiştir.

Anhtar Kelimeler: Catinella olivacea, Belonidium sulphureum, yeni kayıtlar, Türkiye.
\end{abstract}

\section{Introduction}

Helotiales Nannf is the largest order of inoperculate discomycetes within the class Leotiomycetes. Its members are characterized by apothecial, sessile or stipitate, discoid and cupulate or more rarely convex ascomata, thin walled asci without separable wall layers, and mostly hyaline, usually smooth, longitudinally symmetrical, simple or transversely septate ascospores. The order includes 10 families, 501 genera and approximately 3880 taxa which are saprophytic, plant parasites and few lichenized or lignicolous (Hansen and Knudsen, 2000; Kirk et al., 2008).

According to the current literature (Sesli and Denchev, 2008; Akata and Kaya 2012, 2013; Akata et al., 2014a; 2014b; Güngör et al., 2015a; 2015b; Uzun et al., 2013; 2015), 57 species representing 33 genera of the Turkish Helotiales have so far been reported from Turkey.

The study aims to make contribution to the macromycota of Turkey by adding new records.

\section{Materials and methods}

Study materials were collected from Beşikdüzü and Şalpazarı districts (Trabzon) during routine field trips in 2013. Necessary morphological and ecological characteristics of the samples were recorded and they were photographed in their natural habitats. Microscopic data were obtained by using a light microscope, micrometers and necessary chemicals (Melzer's reagent, 5\% $\mathrm{KOH}$ ). Identification was performed with the help of literature (Breitenbach \& Kränzlin, 1984; Hansen and Knudsen, 2000; Medardi, 2006). The specimens are kept at Ankara University Herbarium (ANK).

\section{Results}

Catinella olivacea and Belonidium sulphureum are presented together with short description, ecology, distribution, locality, collection date, photographs related to their macro and micromorphologies are provided. The systematic of the taxa is presented in accordance with Mycobank (http://www.mycobank.org: accessed May 25. 2015). 
Helotiales Nannf

Dermateaceae Fr. $1)$.

Catinella olivacea (Batsch) Boud. (Fig.

Apothecia sessile, 15-40 $\mathrm{mm}$ broad, attached to substrate by thick brownish hyphae; spherical when young, then cup to saucer shaped with upturned margin. Hymenium smooth, yellowish olive to brownish olive when fresh, blackish olive when dry, outer surface furfuraceous and darker than the hymenium (Fig.1a). Asci 90$100 \times 5-8 \mu \mathrm{m}$, cylindrical, eight-spored (Fig.1b,c). Paraphyses septate, cylindrical, slightly swollen at the tips (Fig.1d). Anchor hyphae up to $8 \mu \mathrm{m}$, brown (Fig.1e). Spores uniseriate, 9-11 $\times 4-4.5 \mu \mathrm{m}$, light brown to brownish, smooth, ellipsoid with 2 oil drops (Fig. 1f).

Ecology: October to November, on damp decaying wood (Breitenbach and Kränzlin, 1984).

Specimen examined: Turkey-Trabzon: Şalpazarı, Çarlaklı village, on rotten dead wood of Castanea sativa Miller, $40^{\circ} 58^{\prime} \mathrm{N}-$ $39^{\circ} 11^{\prime} \mathrm{E}, 230 \mathrm{~m}, 26.11 .2013$, Akata \& Yuzun 1533.

Hyaloscyphaceae Nannf.

Belonidium sulphureum (Fuckel)

Raitv. (Fig.2).

Apothecia sessile, 1-2 mm, cup shaped at first, then expanded to plate shaped. Hymenium smooth, dingy to greyish white, outer surface yellowish and covered with yellow to sulphur yellow hairs (Fig.2a). Asci 90-110 × 9-11 $\mu \mathrm{m}$, biseriate, clavate, eightspored, amyloid at apex. Paraphyses non septate, lanceolate, longer than asci (Fig. 2b, c). Hairs $70-150 \times 3-5 \mu \mathrm{m}$, thin walled, yellowish to sulphur yellow and septate (Fig.2d). Spores 19-24 × $3 \mu \mathrm{m}$, hyaline, smooth, cylindrical, generally slightly curved, with 1-5 septa (Fig. 2e).

Ecology: Spring to fall, on herbaceous stems (Breitenbach and Kränzlin, 1984).

Specimen examined: Turkey-Trabzon: Beşikdüzü, Aksaklı village, on dead stems of Phytolacca sp. $41^{\circ} 03^{\prime} \mathrm{N}-39^{\circ} 11^{\prime} \mathrm{E}, 76 \mathrm{~m}$, 28.11.2013, Akata \& Yuzun 1607.

\section{Discussion}

Catinella olivacea is characterized by clusters of distinctive, plane, olive, dark olive to brownish olive apothecia with a distinctly furrowed, ochraceous margin. The apothecia of the fungus usually grows on the underside of damp, rotten wood of broad leaved trees and moss covered logs. Though it is quite difficult to recognize in the field, it could easily be identified due to its distinctive macroscopic and microscopic features (Durand, 1922; Breitenbach \& Kränzlin, 1984; Medardi, 2006).C. melanochlora (Boedijn) Gamundí is macroscopically very close to $C$. olivacea, but the latter species has larger asci and spores (Greif et al., 2007).

Belonidium mollissimum is very close to $B$. sulphureum (Fuckel) Raitv. in terms of ecology and morphology, but the septate and larger spores of $B$. sulphureum easily distinguishes the two taxa from each other (Breitenbach \& Kränzlin, 1984; Hansen and Knudsen, 2000).

With this study, Catinella olivacea and Belonidium sulphureum are reported for the first time from Turkey at generic level, the genus and species numbers of Turkish Helotiales increased to 35 and 59. 


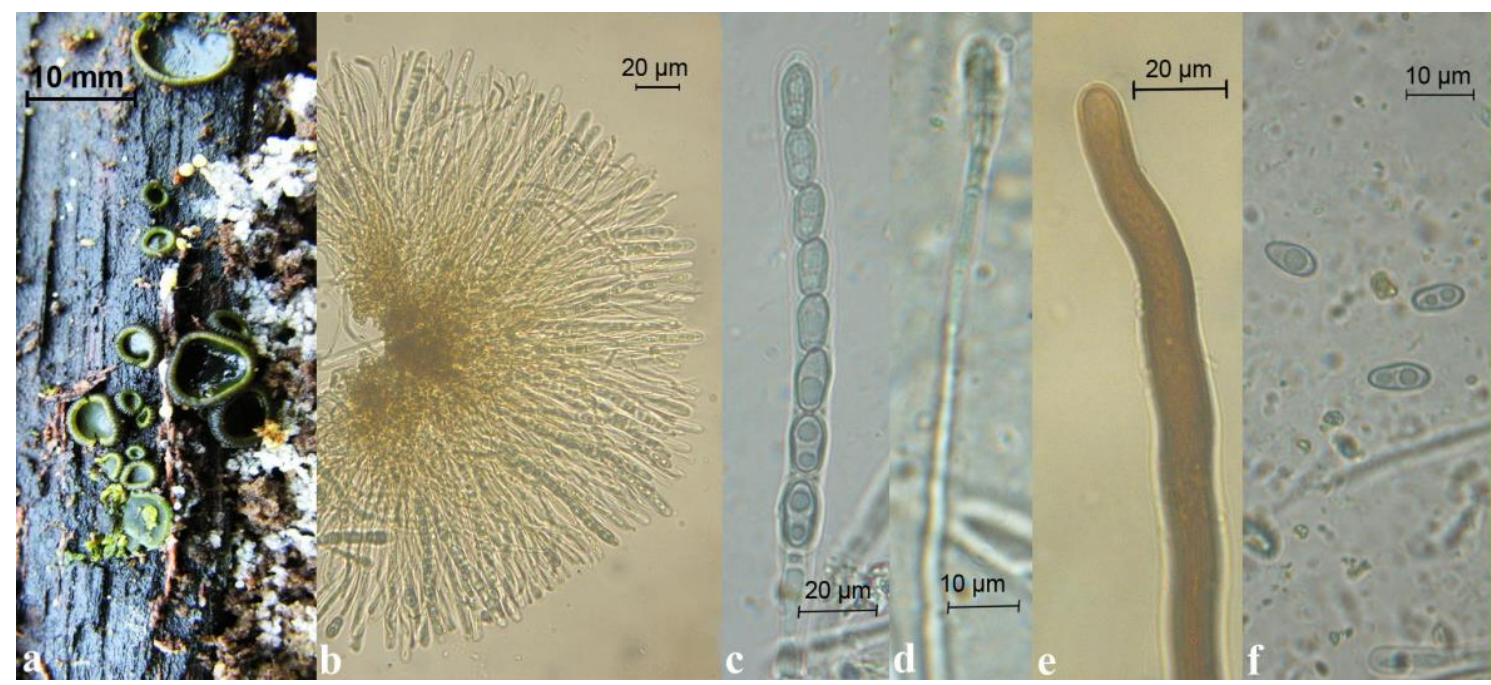

Figure 1. Catinella olivacea: a. apotecia, b. asci, c. single ascus, d. paraphyses, e. anchor hyphae, f. spores.

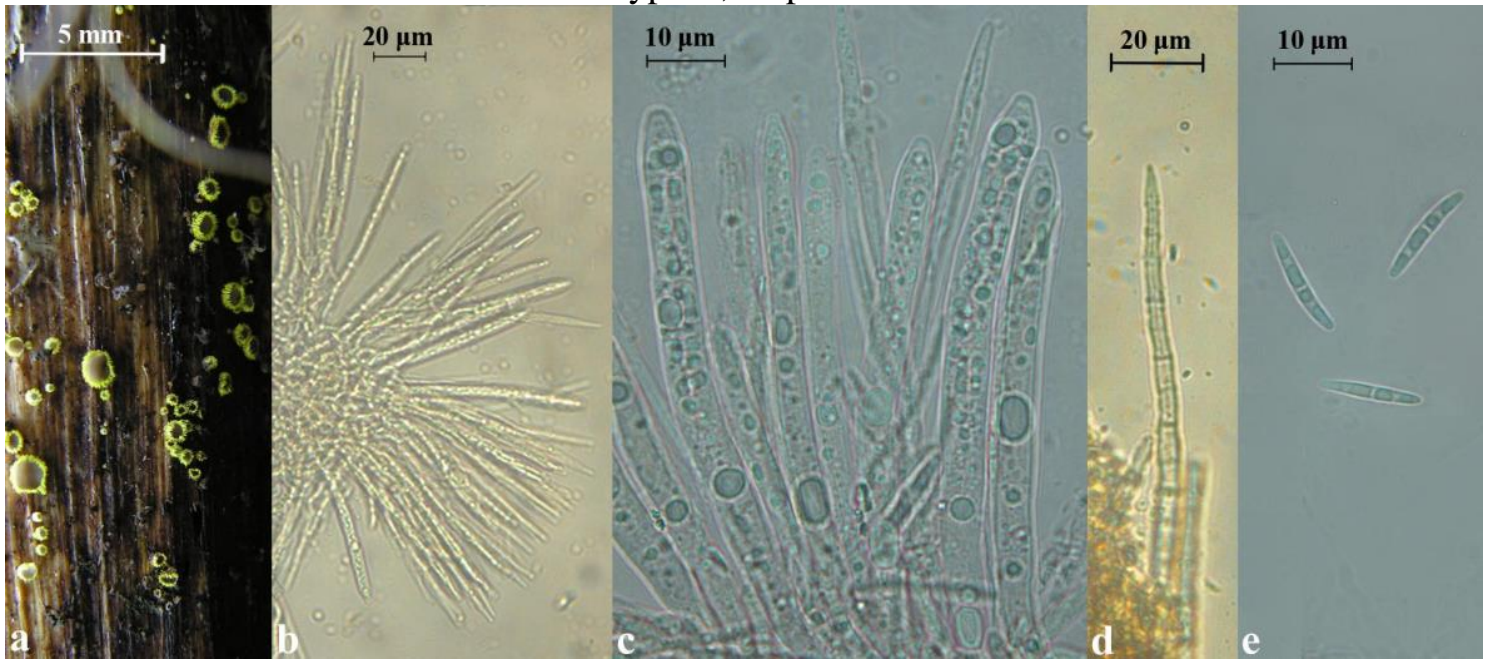

Figure 2. Belonidium sulphureum: a. apotecia, b,c. asci and paraphyses, d. hair, e. spores

\section{References}

Akata, I., Kaya, A. 2012. Two New Additions to Turkish Ascomycota. International Journa1 of Botany 8: 79-81.

Akata, I., Kaya, A.2013. Two earth-tongue genera new for Turkey. Mycotaxon 125: 87-90.

Akata. I., Kaya, A., Uzun, Y. 2014a. Two New Lachnum Records for Turkish Mycobiota. Journal of Applied Biological Sciences 8 (1): 2830.

Akata I., Kaya A., Uzun Y. 2014b. Macromycetes determined in Yomra (Trabzon) district. Turkish Journal of Botany, 38: 999-1012.

Breitenbach, J., Kränzlin, F. 1984. Fungi of Switzerland, vol. 1. Lucerne, Verlag Mykologia.
Durand, E.J. 1922. The Genus Catinella. Bulletin of the Torrey Botanical Club 49 (1): 1521.

Greif, M.D., Gibas, C.F.C., Tsuneda, A., Currah, R.S. 2007. Ascoma Development and P hylogeny of an Apothecioid Dothideomycete, Catinella olivacea. American Journal of Botany 94 (11): 1890-1899.

Güngör, H., Şen, İ., Allı, H., Solak, M.H. 2015a. Two new Ascomycete records for Turkish Mycota. Biological Diversity and Conservation 8(1):19-21.

Güngör, H., Çolak, Ö.F., Yaratanakul Güngör, M., Solak, M.H. 2015b. New Ascomycete (Geoglossum umbratile, Peziza lobulata) records for Turkey. Biological Diversity and Conservation 8(2):1-3. 
Hansen, L., Knudsen H. 2000. Nordic Macromycetes (Ascomycetes). Vol.1. Copenhagen: Nordsvamp.

Kirk P.F., Cannon, P.F., Minter D.W., Stalpers J.A. 2008. Dictionary of the fungi, 10th ed. CAB International. Wallingford, UK.

Medardi, G. 2006. Ascomiceti d'Italia. Trento, Centro Studi Micologici.

Sesli E., Denchev, C.M. 2008. Checklists of the myxomycetes, larger ascomycetes, and larger basidiomycetes in Turkey. - Mycotaxon 106: 6567. + [complete version, 1-36, new version uploaded in February 2014].

URL: (http://www.mycobank.org: accessed April 25. 2015.

Uzun Y., Acar İ., Akata I., Akçay M.E. 2013. Three new records for Turkish Cortinarius from Bingöl province. Biological Diversity and Conservation, 6 (3): 160-163.

Uzun, Y., Kaya, A., Karacan, İ.H., Kaya, Ö.F., Yakar, S. 2015. Neobulgaria Petr. and Trichopeziza Fuckel, Two New Genus Record for Turkish Lachnaceae. Mantar Dergisi 6 (2): 58-61. 